\title{
PENERAPAN PROTOKOL KESEHATAN PADA LAYANAN UPT PERPUSTAKAAN UNTAN DI MASA PANDEMI COVID-19
}

\author{
Winda, Sisilya Saman Madeten \\ Program Studi Diploma 3 Perpustakaan FKIP Untan Pontianak \\ Email: winda@untan.com
}

\begin{abstract}
This study discusses the Application of Health Protocols at the Untan Library UPT Services during the Covid-19 Pandemic. The purpose of the study was to determine the application of health protocols to Untan Library services and the obstacles faced by the Untan Library in implementing health protocols. This study uses descriptive qualitative methods with data collection techniques, namely observation, interviews and documentation. The data sources of this research are the head of the library, librarians and users. The results showed that the Untan Library UPT opened all services during the covid-19 pandemic with the stipulation of health protocols for all services. So that the service process that takes place is carried out in a different way, namely the obligation to apply $3 M$ (washing hands, wearing masks, maintaining distance) when entering the library, the process of borrowing collections, returning collections, using collections in on-site reading services and providing online services for users who will make loan free letter. The obstacles faced are the concerns of librarians in serving users during the pandemic, users who do not comply with health protocols and users' dissatisfaction with services.
\end{abstract}

Keywords: Covid-19 Pandemic, Health Protocol, Library Service, Service Process.

\section{PENDAHULUAN}

Indonesia merupakan negara yang termasuk dalam beberapa negara terdampak covid-19. Hal ini sangat berpengaruh dalam kebiasaan hidup masyarakat di Indonesia, baik dalam segi perekonomian, sosial bahkan hingga pendidikan. Terhitung sejak awal bulan Maret tahun 2020, dampaknya sangat terasa terhadap kegiatan belajar mengajar. Hal ini terlihat dari adanya Surat Edaran Kementerian Pendidikan dan Kebudayaan (Kemendikbud) Nomor 4 Tahun 2020 tentang pelaksanaan kebijakan pendidikan dalam masa darurat penyebaran covid-19 yaitu proses pembelajaran dilakukan secara daring atau jarak jauh, aktivitas dan tugas pembelajaran dilakukan dirumah masingmasing agar mencegah penyebaran covid-19.

Pembelajaran yang dilakukan secara daring ini juga dirasakan oleh mahasiswa. Sehingga perlunya fasilitas teknologi informasi dan komunikasi untuk menunjang proses pembelajaran, seperti handphone dan laptop. Selain fasilitas pendukung berupa teknologi, mahasiswa juga membutuhkan sumber informasi yang relevan berupa buku, jurnal, skripsi, tesis dan lain-lain. Terutama bagi mahasiswa semester akhir sangat memerlukannya sumber referensi untuk digunakan sebagai acuan dalam mengerjakan karya tulis ilmiah. Dengan begitu kehadiran perpustakaan sangatlah penting walaupun pada masa pandemi sekarang ini.

Menurut Undang-undang Republik Indonesia Nomor 43 Tahun 2007 tentang perpustakaan. Perpustakaan adalah institusi pengelola karya tulis, karya cetak, dan/atau karya rekam secara professional dengan sistem yang baku guna memenuhi kebutuhan pendidikan, penelitian, pelestarian, informasi, dan rekreasi para pemustaka. Layanan 
pemustaka merupakan layanan yang berhubungan langsung dengan pemustaka atau disebut juga dengan layanan perpustakaan (Rahayu, 2015). Layanan perpustakaan yang umumnya dimanfaatkan oleh pemustaka ialah layanan sirkulasi dan layanan referensi, yang biasanya pemustaka mengaksesnya secara langsung yaitu dengan mendatangi gedung perpustakaan.

Pandemi covid-19 menjadi sebuah tantangan bagi pustakawan dalam memberikan layanan langsung terhadap pemustaka. Dengan demikian, perpustakaan dituntut untuk berinovasi dalam melayani pemustaka agar tetap dapat memberikan layanan di masa pandemi ini. Perpustakaan dapat membuka layanan pada masa pandemi covid-19 dengan memperhatikan protokol kesehatan. Layanan dibuka secara terbatas dengan diterapkannya protokol kesehatan seperti pengukuran suhu badan, penggunaan masker, penyediaan hand sanitizer, tempat cuci tangan dan sabun, pembatasan jarak antar pemustaka maupun pustakawan dan adanya pengurangan kapasitas pemustaka.

Menurut Basuki (2011) perpustakaan perguruan tinggi ialah perpustakaan yang terdapat pada perguruan tinggi, badan bawahannya maupun lembaga yang berafiliasi dengan perguruan tinggi, dengan tujuan utama membantu perguruan tinggi mencapai tujuannya. Perpustakaan Untan merupakan perpustakaan perguruan tinggi yang membuka layanan pada masa pandemi covid-19. Pada awal pandemi UPT Perpustakaan Untan menutup pelayanan perpustakaan, dan kemudian pada bulan November tahun 2020 UPT Perpustakaan Untan membuka kembali layanan perpustakaan. Dengan dibukanya layanan, UPT Perpustakaan Untan menerapkan protokol kesehatan guna memutus rantai penyebaran covid-19. Protokol kesehatan ini diterapkan tidak hanya untuk pemustaka namun pustakawan, karyawan dan petugas kebersihan juga menerapkannya.
Terdapat beberapa protokol kesehatan yang diterapkan di UPT Perpustakaan Untan, meliputi pengukuran suhu badan, penyediaan hand sanitizer di beberapa titik di setiap layanan, disediakanya sabun dan tempat untuk mencuci tangan sebelum masuk ke Perpustakaan Untan. Pada layanan baca adanya pembatasan jarak antar pemustaka yang satu dengan yang lain dan diwajibkan untuk menggunakan masker.

\section{METODE PENELITIAN}

Metode penelitian yang dilakukan menggunakan metode penelitian kualitatif deskriptif dengan teknik pengumpulan data berupa kegiatan observasi, wawancara dan dokumentasi. Adapun narasumber dalam penelitian ini yaitu kepala perpustakaan, pustakawan dan pemustaka.

\section{HASIL PENELITIAN DAN PEMBAHASAN}

\section{Hasil}

Perpustakaan merupakan sarana utama dalam mensukseskan pencapaian lembaga pendidikan yang menaunginya. Pada prinsipnya, semua kegiatan yang dilakukan sebuah perpustakaan ditujukan untuk pemustaka. Masa pandemi sekarang ini menjadi salah satu penghalang bagi pemustaka untuk dapat berkunjung ke perpustakaan. Masa pandemi covid-19 menuntut perpustakaan untuk dapat berinovasi dalam memberikan layanan perpustakaan, baik layanan yang berbentuk online ataupun layanan yang berhubungan langsung dengan pemustaka. Perpustakaan perguruan tinggi yang membuka layanan di masa pandemi diharapkan untuk dapat menerapkan protokol kesehatan untuk mencegah terjadinya penyebaran wabah covid-19.

Pada masa pandemi UPT Perpustakaan Untan membuka jam layanan perpustakaan. Sehingga diberlakukannya penerapan protokol kesehatan di Perpustakaan Untan demi keamanan dan kenyamanan bersama. 
Layanan-layanan yang dibuka pada Perpustakaan Untan di masa pandemi sama dengan sebelum pandemi. Protokol kesehatan yang diterapkan di Perpustakaan Untan ialah mencuci tangan sebelum masuk perpustakaan, menggunakan masker, menggunakan hand sanitizer, pengecekan suhu, pembatasan jarak antar pemustaka maupun pustakawan, pengurangan jam layanan dan pengurangan jumlah pengunjung. Protokol kesehatan ini diterapkan pada setiap aktivitas yang dilakukan pada semua layanan, sehingga proses pelayanan yang terjadi berbeda pada saat pandemi. Proses pelayanan yang berbeda ialah dimulai dari awal masuk perpustakaan yang mewajibkan pemustaka untuk menerapkan 3M (mencuci tangan, memakai masker, menjaga jarak), proses peminjaman koleksi, proses pengembalian koleksi, proses penggunaan koleksi perpustakaan pada layanan baca ditempat dan tersedianya layanan online untuk pembuatan surat bebas pinjam perpustakaan.

\section{Pembahasan}

Berdasarkan hasil penelitian yang dilakukan oleh penulis, penerapan protokol kesehatan pada layanan layanan UPT Perpustakaan Untan dimasa pandemi covid19 dapat diuraikan sebagai berikut.

1. Layanan Sirkulasi

a. Peminjaman buku

Proses peminjaman buku dimulai dari pemustaka menyerahkan kartu anggota serta buku yang akan dipinjam kepada pustakawan dan kemudian pustakawan melakukan proses administrasi peminjaman. Pada saat peminjaman koleksi pemustaka dan pustakawan diwajibkan untuk tetap menjaga jarak dimasa pandemi ini. Pada Perpustakaan Untan terdapat plastik sekat pembatas antara pemustaka dengan pustakawan dan disediakannya hand sanitizer pada setiap sisi.
Proses perpanjangan masa peminjaman buku sama halnya dengan peminjaman buku yaitu dimulai dari pemustaka memberikan buku serta kartu anggota setelah itu pustakawan melakukan proses administrasi dan kemudian pustakawan memberikan kembali buku kepada pemustaka dengan aturan tetap menjaga jarak.

b. Pengembalian buku

Pada saat pengembalian buku, pustakawan tidak langsung menerima buku, namun pustakawan langsung melakukan proses administrasi pengembalian buku dan kemudian buku tersebut disimpan pada tempat penampung yang telah disediakan oleh pustakawan. Setelah itu pustakawan melakukan penyemprotan pada buku tersebut dan kemudian didiamkan selama satu hari sebelum buku disimpan kembali ke rak. Pendapat ini berdasarkan hasil wawancara yang dilakukan pada (5 Agustus 2021) yang mengatakan bahwa : "kami tidak langsung menerima buku pada saat pengembalian. Buku yang telah dikembalikan kemudian ditampung pada tempat yang telah kami sediakan, setelah itu kami semprot dengan disinfektan dan didiamkan selama satu hari".

Menurut Surat Edaran Perpustakaan Nasional terdapat ketentuan terhadap koleksi yang dipinjam diluar yaitu setiap koleksi yang telah dikembalikan harus dikarantina ditempat yang ditentukan selama $2 \times 24$ jam dan jika koleksi yang sedang dikarantina akan dibutuhkan oleh pemustaka akan dilayankan kembali setelah karantina selesai.

2. Layanan Koleksi Cadangan (ORB)

Layanan koleksi cadangan menyediakan koleksi buku-buku yang merupakan cadangan dari seluruh judul koleksi yang dimiliki Perpustakaan 
Untan. Pada layanan ini pemustaka dapat mencari dan menggunakan buku yang sudah tidak ada pada layanan sirkulasi. Pemustaka yang ingin menggunakan koleksi pada layanan ini wajib menyerahkan KTM pada meja pustakawan. Koleksi pada layanan ini hanya bisa dibaca ditempat dan difotocopy. Perpustakaan Untan menyediakan tempat untuk pemustaka membaca koleksi berupa tempat baca berbentuk lesesan dan berupa meja kursi.

Pada tempat baca yang berupa meja kursi terdapat pengurangan jumlah kursi, yang sebelum pandemi setiap meja berisikan empat kursi namun dimasa pandemi menjadi dua kursi pada tiap meja. Kemudian pada tempat baca yang berupa lesehan diberikannya tanda silang. Pemberian tanda silang ini untuk memberitahukan pembatasan jarak antar pemustaka. Pendapat ini berdasarkan hasil wawancara yang dilakukan pada (5 Agustus 2021) yang mengatakan bahwa : "pembatasan jumlah pemustaka dihitung dari pengurangan tiap kursi dan tempat baca, misalnya seperti pengurangan dalam tiap meja yang awalnya setiap meja disiapkan empat kursi setelah pandemi menjadi dua kursi dan adanya pengurangan pada layanan baca ditempat dengan diadakannya tanda silang untuk memberikan batas jarak antar pemustaka satu dengan yang lain". Menurut Surat Edaran Perpustakaan Nasional, pemustaka wajib selalu menjaga jarak (physical distancing) minimal 1 meter antar pemustaka maupun pustakawan dan dilarang berkerumun.

3. Layanan Koleksi Referensi

Koleksi yang terdapat pada layanan referensi Perpustakaan Untan berupa kamus, ensiklopedia, prosiding. Koleksi dilayanan ini hanya dapat dibaca ditempat. Pemustaka yang ingin menggunakan koleksi pada layanan ini wajib menyerahkan KTM pada meja pustakawan. Dimasa pandemi pemustaka diwajibkan untuk menggunakan masker dan menjaga jarak. Koleksi yang telah digunakan oleh pemustaka akan disemprotkan disinfektan terlebih dahulu oleh pustakawan kemudian didiamkan selama satu hari sebelum koleksi disimpan kembali ke rak koleksi. Pendapat ini berdasarkan hasil wawancara yang dilakukan pada (10 Agustus 2021) yang mengatakan bahwa : "melakukan penyemprotan dengan di disinfektankan terhadap koleksi yang telah digunakan sebelum dimasukkan ke rak lagi”. Menurut Surat Edaran Perpustakaan Nasional, terdapat ketentuan terhadap koleksi yang dibaca ditempat yaitu koleksi harus dikarantina ditempat yang telah ditentukan selama 2x24 jam dan jika koleksi yang sedang dikarantina akan dibutuhkan akan dilayankan kembali setelah karantina selesai.

4. Layanan KKI (Koleksi Karya Ilmiah)

Perpustakaan Untan menyediakan layanan koleksi karya ilmiah berupa laporan penelitian yang terdiri tugas akhir, skripsi, tesis dan disertasi. Koleksi karya ilmiah ini hanya dilayankan untuk baca ditempat dan difotocopy. Pemustaka yang ingin menggunakan koleksi pada layanan ini wajib menyerahkan KTM pada meja pustakawan. Koleksi karya ilmiah ini dapat di fotocopy namun dengan ketentuan yang telah ditetapkan Perpustakaan Untan yaitu yang dapat difotocopy pada bab 1 , bab 2 dan pada bab metode penelitian maksimal 5 lembar. Pada penerapan protokol kesehatan pemustaka wajib memakai masker dan menjaga jarak antara pemustaka dan pustakawan serta pemustaka dengan pemustaka lainnya. Pengunaan koleksi pada layanan koleksi karya ilmiah sama halnya dengan penggunaan koleksi pada layanan referensi sehingga penerapan protokol kesehatan pada layanan koleksi karya ilmiah sama dengan layanan referensi.

5. Layanan Koleksi Terbitan Berseri

Layanan koleksi terbitan berseri Perpustakaan Untan menyediakan koleksi yang berupa surat kabar, majalah, 
jurnal. Koleksi pada layanan ini hanya untuk baca ditempat. Pada layanan ini disediakan meja dan kursi untuk mahasiswa yang ingin menggunakan koleksi. Pada penerapan protokol kesehatan mahasiswa wajib memakai masker dan menjaga jarak antara pemustaka dan pustakawan serta pemustaka dengan pemustaka lainnya. Pembatasan jarak antar mahasiswa yaitu dengan pengurangan jumlah kursi pada tiap meja.

6. Layanan Administrasi

Kegiatan layanan administrai di UPT Perpustakaan Untan meliputi pelayanan yang berhubungan dengan tata persuratan, administrasi keanggotaan dan bebas perpustakaan. Surat yang masuk maupun surat yang keluar merupakan kegiatan yang dilakukan pada layanan administrasi. Keanggotaan pada Perpustakaan Untan terdiri dari mahasiswa, dosen, karyawan untan, alumni dan masyarakat umum diluar untan.

Pada masa pandemi kegiatan surat menyurat dan pendaftaran keanggotaan Perpustakaan Untan wajib menerapkan protokol kesehatan seperti mencuci tangan sebelum masuk perpustakaan, menggunakan masker dan menjaga jarak. Namun untuk pembuatan surat bebas pinjam perpustakaan pada masa pandemi dilakukan secara online, dengan diberikannya link untuk daftar secara online. Hal ini dilakukan agar tidak terjadi kerumunan pada saat pembuatan surat bebas pinjam perpustakaan. Pendapat ini berdasarkan hasil wawancara yang dilakukan pada (5 Agustus 2021) yang mengatakan bahwa : "Diadakannya layanan online khusus mahasiswa yang akan membuat surat bebas pinjam koleksi perpustakaan. Diberikannya link untuk daftar online surat bebas pinjam koleksi perpustakaan yang nantinya pemustaka diharuskan mengupload data diri di email perpustakaan untan dan kemudian pengambilan surat tersebut tetap datang ke perpustakaan untan, hal ini dilakukan supaya mahasiswa tidak beramai datang ke perpustakaan”.

7. Layanan Fotocopy

Pada layanan fotocopy pemustaka dapat memfotocopy koleksi yang tidak dapat dibawa pulang. Namun dalam memfotocopy koleksi terdapat aturan sesuai dengan koleksi yang akan difotocopy. Pada Perpustakaan Untan terdapat syarat dalam memfotocopy koleksi, seperti koleksi karya tulis ilmiah yang hanya bisa difotocopy pada bab 1 dan 2 , serta bab metode penelitian yang hanya bisa difotocopy maksimal lima lembar.

Pemustaka yang akan memfotocopy koleksi memberitahukan pustakawan terlebih dahulu koleksi yang akan difotocopy. Kemudian pustakawan memberi kertas bon yang nantinya kertas tersebut pemustaka berikan kepada pustakawan pada layanan fotocopy. Pada kertas bon tersebut bertuliskan halaman koleksi yang akan difotocopy serta biaya yang harus dibayar dalam memfotocopy. Dengan begitu, pustakawan pada layanan fotocopy hanya memfotocopy koleksi sesuai dengan yang ditulis di kertas bon. Pada penerapan protokol kesehatan pemustaka wajib memakai masker, menggunakan hand sanitizer, menjaga jarak antara pemustaka dan pustakawan serta pemustaka dengan pemustaka lainnya.

8. Layanan Penitipan Tas

Pada layanan penitipan tas ini pemustaka dapat menyimpan barangbarang bawaan seperti tas, jaket dan lainlain yang tidak diperbolehkan untuk dibawa masuk ke ruangan layanan Perpustakaan Untan. Terdapat beberapa barang yang dapat dibawa keruangan layanan seperti alat tulis, laptop, hand phone, dan barang penting lainnya. Penerapan protokol kesehatan pada layanan ini pemustaka wajib mengecek suhu terlebih dahulu, menggunakan masker, menjaga jarak antara pemustaka 
dan pemustaka lain serta pemustaka dengan pustakawan.

9. Layanan Teknis

Kegiatan layanan teknis di Perpustakaan merupakan kegiatan yang berhubungan dengan persiapan penyajian bahan pustaka hingga siap dilayankan. Kegiatan layanan teknis di Perpustakaan Untan terdiri dari pengadaan, inventaris, mengentri, klasifikasi, penempelan chip, penempelan barcode, penempelan nomor punggung, menyampul, dan pengecekan keaktifan chip. Penerapan protokol kesehatan pada layanan ini pustakawan wajib menggunakan masker dan menjaga jarak antar pustakawan dengan pustakawan lainnya.

\section{Kendala yang dihadapi dalam menerapkan protokol kesehatan}

Berdasarkan hasil wawancara yang dilakukan di UPT Perpustakaan Untan peneliti menemukan kendala dalam menerapkan protokol kesehatan yang dapat diuraikan sebagai berikut.

1. Kekhawatiran pustakawan dalam melayani pemustaka dimasa pandemi covid-19

Membuka layanan perpustakaan dimasa pandemi merupakan salah satu tantangan yang harus dihadapi seorang pustakawan. Dengan membuka layanan perpustakaan berarti adanya interaksi yang dilakukan antara pustakawan dengan pemustaka. Interaksi yang dilakukan ialah seperti melakukan peminjaman koleksi, pengembalian koleksi, memfotocopy koleksi dan sebagainya. Tantangan yang dihadapi pustakawan seperti timbulnya rasa kekhawatiran dan ketakutan pustakawan akan terpaparnya virus covid-19 terhadap pemustaka yang berkunjung ke perpustakaan. pendapat ini berdasarkan hasil wawancara yang dilakukan pada (10 Agusus 2021) yang mengatakan bahwa : "Pemustaka itukan datang dari berbagai tempat jadi kami juga ada rasa khawatir mereka yang membawa virus, jadi ya dari pihak pustakawan dan pemustaka harus saling menjaga diri dan juga wajib menerapkan prokes". Dengan begitu perlunya kesiapan yang dilakukan pustakawan dalam melayani pemustaka di masa pandemi. Menurut Surat Edaran Perpustakaan Nasional, terdapat ketentuan bagi pustakawan yaitu wajib menggunakan masker, wajib mencuci tangan, wajib mengukur suhu, menerapkan etika batuk, bersin dan tidak meludah sembarangan, wajib memakai alat pelindung diri (face shield, sarung tangan), selalu menjaga jarak, membawa dan menggunakan perlengkapan pribadi.

2. Pemustaka yang kurang mematuhi protokol kesehatan

Dari beberapa protokol kesehatan yang telah diterapkan masih terdapat pemustaka yang tidak mematuhi atau tidak menerapkan protokol kesehatan yang telah diterapkan di Perpustakaan Untan. Pemustaka kurang memperdulikan pentingnya menerapkan protokol kesehatan seperti tidak menggunakan masker pada saat berkunjung ke perpustakaan, tidak mau menggunakan hand sanitizer dan kurangnya menjaga jarak antar tiap pemustaka. Pendapat ini berdasarkan hasil wawancara yang dilakukan pada (10 Agustus 2021) yang mengatakan bahwa : "Banyak mahasiswa yang tidak menggunakan masker, disuruh pakai hand sanitizer nggak mau, kurangnya jaga jarak antar mahasiswa".

Protokol kesehatan diterapkan di perpustakaan ialah untuk memberikan rasa aman dan nyaman ketika berkunjung ke perpustakaan. Namun, dengan kurangnya kepedulian terhadap protokol kesehatan dapat menimbulkan efek yang tidak baik bagi pemustaka dan juga pustakawan. Dengan begitu tindakan yang dilakukan pustakawan terhadap pemustaka yang tidak mematuhi protokol kesehatan yang telah diterapkan di Perpustakaan Untan ialah dengan memberikan teguran dalam arti untuk selalu mengingatkan pentingnya protokol kesehatan. Khusus pada pemustaka yang 
tidak menggunakan masker, pustakawan melarang pemustaka untuk masuk ke dalam perpustakaan. Tindakan ini dilakukan untuk memberikan kesadaran terhadap pemustaka akan pentingnya protokol kesehatan selama masa pandemi ini. Pendapat ini berdasarkan hasil wawancara yang dilakukan pada (10 Agustus 2021) yang mengatakan bahwa : "Melarang pemustaka masuk kalau mereka tidak memakai masker, juga memberikan teguran". Menurut Surat Edaran Perpustakaan Nasional, pustakawan wajib memberikan teguran kepada pemustaka jika tidak melaksanakan protokol kesehatan yang telah ditentukan.

3. Kurang puasnya pemustaka terhadap layanan

Pada masa pandemi terdapat perubahan yang dirasakan pemustaka terhadap layanan di perpustakaan. Perubahan yang dirasakan seperti berkurangnya jam layanan perpustakaan. Hal ini dilakukan agar pemustaka tidak berkumpul berlama-lama di perpustakaan. Namun dengan adanya pengurangan jam layanan ini menyebabkan pemustaka dalam menggunakna koleksi yang ada dengan tergesa-gesa sehingga menimbulkan rasa ketidakpuasan pemustaka terhadap layanan di perpustakaan. Pendapat ini berdasarkan hasil wawancara yang dilakukan pada (5 Agustus 2021) yang mengatakan bahwa : "kurang puasnya mahasiswa terhadap layanan karena dikurangnya jam waktu kunjung, ya tapi gimana juga karena ini masa pandemi ya"

\section{SIMPULAN DAN SARAN Simpulan}

Berdasarkan hasil dari penelitian, maka diperoleh kesimpulan yaitu pada masa pandemi Perpustakaan Untan tetap membuka semua layanan perpustakaan yang ada. Dengan tetap membuka semua layanan maka dilakukannya penerapan protokol kesehatan.
Penerapan protokol kesehatan diterapkan tidak hanya untuk pemustaka namun juga pustakawan serta petugas kebersihan. Protokol kesehatan yang diterapkan di Perpustakaan Untan ialah mencuci tangan sebelum masuk perpustakaan, menggunakan masker, menggunakan hand sanitizer, pengecekan suhu, pembatasan jarak antara pemustaka maupun pustakawan, pengurangan jam layanan dan pengurangan jumlah pengunjung. Protokol kesehatan tersebut diterapkan pada setiap aktivitas yang dilakukan pada semua layanan, sehingga proses pelayanan yang terjadi berbeda pada saat pandemi. Proses pelayanan yang berbeda dimulai dari awal masuk perpustakaan yang mewajibkan pemustaka untuk menerapkan 3M (mencuci tangan, memakai masker, menjaga jarak), proses peminjaman koleksi, proses pengembalian koleksi, proses penggunaan koleksi di perpustakaan pada layanan baca ditempat dan disediakannya layanan online untuk pemustaka yang akan membuat surat bebas pinjam.

\section{Saran}

Berdasarkan hasil penelitian, maka hal yang dapat disarankan yaitu diharapkan Perpustakaan Untan dapat membuat link untuk pemesanan buku. Melalui pemesanan buku yang telah dilakukan maka pemustaka datang ke perpustakaan hanya untuk mengambil buku yang telah dipesan, dengan begitu pemustaka tidak perlu berlama-lama di perpustakaan. Kemudian diharapkan Perpustakaan Untan dapat membuat link untuk pemesanan kursi. Melalui pemesanan yang dilakukan maka pemustaka yang dapat menetap di dalam perpustakaan ialah pemustaka yang telah dahulu memesan kursi. Dengan begitu pemustaka dapat duduk sesuai dengan kursi yang telah dipesan sehingga tidak ada lagi pemustaka yang saling berdekat-dekatan.

\section{DAFTAR RUJUKAN}

Basuki, S. (2011). Pengantar Ilmu Perpustakaan. Jakarta: Universitas Terbuka. 
Indonesia. (2007). Undang-undang Republik Indonesia Nomor 43 Tahun 2007 Tentang Perpustakaan.

https://tinyurl.com/mrymv4ba

Diakses pada tanggal 26 Mei 2021.

Nasional, P. (2020). Surat Edaran Perpustakaan Nasional Nomor 3497 Tentang Layanan Perpustakaan Nasional Dalam Tatanan Normal Baru. Retrieved from https://jdih.perpusnas.go.id/file_perat uran/Surat Edaran Layanan.pdf. Diakses pada tanggal 27 Mei 2021.
Rahayu, L., K, R. A., Sumiati, O., Makariam, L., \& Permatasari, R. B. (2015). Layanan Perpustakaan. Tanggerang Selatan: Universitas Terbuka.

Shabibie. (2020). Surat Edaran Mendikbud No. 4 Tahun 2020 Tentang Pelaksanaan Kebijakan Pendidikan dalam Masa Darurat Penyebaran Coronavirus Disease (COVID-19). https://tinyurl.com/7mwx9fw

Diakses pada tanggal 12 April 2021 di Pusat Pendidikan dan Pelatihan Pegawai Kemendikbud Ristek. 